\title{
Association of Hypertriglyceridemia with Ischemic Stroke, Study in a Tertiary Care Hospital in Bangladesh
}

\author{
MD. ENAMUL KARIM,${ }^{1}$ SHEKHAR KUMAR MONDAL, ${ }^{2}$ AKM HUMAYON KABIR,${ }^{3}$ PARTHA PRATIM DAS, ${ }^{4}$ \\ SARMISTHA BISWAS, ${ }^{3}$ NIGAR SULTANA AHMED ${ }^{2}$
}

\begin{abstract}
Background: Hypertriglyceridemia fosters the development of atherosclerosis via several mechanisms and lead to ischemic stroke (IS) through its contribution to thrombogenicity. The association of hypertriglyceridemia with ischemic stroke was evaluated in this study.

Methods: This was a case control study conducted in the Department of Medicine, Dhaka Medical College Hospital and data was collected in a questionnaire from January to June'2013. Patients presented with ischemic stroke, confirmed by CT scan of Head/ MRI of brain from I day to 6 months and other than ischemic stroke patients were considered as case and control respectively.

Results: The mean age was found $61.0 \pm 8.3$ years in case group and $60.5 \pm 8.1$ years in control group. Male were predominant in both groups which was 80 (80.0\%) in case group and 84 (84.0\%) in control group. More than two third (68.0\%) in cases and one fourth (25.0\%) in controls patients had hypertension. 12 (12.0\%) in cases and 2 (2.0\%) in controls patients had heart disease. Normal triglycerides was found 52 (52.0\%) in cases and 72 (72.0\%) in control. The mean TG was found $179.9 \pm 62.8 \mathrm{mg} / \mathrm{dl}$ in cases and $148.0 \pm 51.9 \mathrm{mg} / \mathrm{dl}$ in controls. Desirable cholesterol was found $16(16.0 \%)$ in cases and $25(25.0 \%)$ in controls. The mean cholesterol was found $238.0 \pm 4.0 \mathrm{mg} / \mathrm{dl}$ in cases and $213.0 \pm 42.0$ in controls. Optimal LDL was found I 2 (I2.0\%) and I8 (I8.0\%) in case and control group respectively. Mean LDL was found $167.0 \pm 35.2$ $\mathrm{mg} / \mathrm{dl}$ in cases and $141.0 \pm 36 . \mathrm{lmg} / \mathrm{dl}$ in controls. Low HDL was found 64 (64.0\%) in cases and 26 (26.0\%) in controls. Mean HDL was found $41.2 \pm 10.6 \mathrm{mg} / \mathrm{dl}$ in case group and $49.0 \pm 8.6 \mathrm{mg} / \mathrm{dl}$ in control group.
\end{abstract}

Conclusion: Ischemic stroke is significantly associated with a higher level of TC,TG, LDL and HDL (inversely). Therefore, Hypercholesterolemia and Hypertriglyceridemia may be a risk factor for ischemic stroke.

Keywords: Ischemic stroke, Triglyceride (TG), Low density lipoprotein (LDL), High density lipoprotein (HDL).

\section{Introduction:}

Stroke is one of the leading causes of death in the world, and the leading cause of acquired disability in adults in most regions. ${ }^{1-2}$ Countries of low and middle income have the largest burden of stroke, accounting for more than $85 \%$ of stroke mortality worldwide, but few reliable data are available to identify risk factors for stroke in most of these regions, and particularly for hemorrhagic stroke. ${ }^{1-5}$

In Asia, the problem of stroke has a particularly strong impact, not only because more than half of the world's

1. Professor \& Head, Dept. of Medicine, Dhaka Medical College \& Hospital.

2. Assistant Registrar, Dept. of Medicine, Dhaka Medical College \& Hospital.

3. Assistant Professor of Medicine, Dhaka Medical College \& Hospital.

4. Associate Professor of Medicine, Dhaka Medical College \& Hospital.

Corresponding author: Prof. Dr. Md. Enamul Karim, Professor \& Head, Dept. of Medicine, Dhaka Medical College \& Hospital, Dhaka, Bangladesh. E-mail: drenamul_karim@yahoo.com. population lives in Asia, but stroke is the predominant vascular disease in many parts of Asia. ${ }^{1}$ In1990 alone, World Health Organization estimated that there were over 2.1 million people who died of stroke In Asia. ${ }^{2}$ The burden of stroke is likely to increase substantially in the near future because of the aging population. Stroke is the second leading cause of death worldwide, and the leading cause of acquired disability in adults in most regions. Apart from implementing effective stroke prevention programs, identification of factors associated with more severe stroke may help to ease the burden of this coming epidemic. ${ }^{3-5}$

Due to the tremendous burden that stroke places on our society, there have been major efforts to identify modifiable risk factors that could reduce the incidence of ischemic stroke (IS). Multiple independent risk factors for IS have been identified. The most prevalent of these include hypertension, diabetes mellitus, smoking, atrial fibrillation, coronary artery disease, congestive heart failure and disorders of lipid metabolism. Epidemiologic studies suggest that elevated total cholesterol and low-density lipoprotein cholesterol (LDL- 
C), as well as low levels of high-density lipoprotein cholesterol (HDL-C) are possible risk factors for IS. ${ }^{6-7}$ Cholesterol and triglycerides are the 2 main lipids found in the body. Triglycerides (triacylglycerols) are the main storage form of fatty acids. They are esters of fatty acids and trihydric-alcohol-glycerol.

The metabolic pathways of triglycerides and HDL-C are related, and an increase in one will usually be accompanied by a decrease in the other (a rise in the HDL-C level will be accompanied by a drop in the triglyceride level, and vice versa)..$^{8-9}$

Hypertriglyceridemia may lead to IS through its contribution to atherosclerosis and/or thrombogenicity. Studies suggest that hypertriglyceridemia fosters the development of atherosclerosis via several mechanisms. Postprandial hypertriglyceridemia in diabetic patients was found to produce endothelial dysfunction, oxidative stress due to lipidderived free radicals, and impairment of endotheliumdependent vasodilatation. ${ }^{10}$ Triglyceride-rich lipoproteins, including very-low-density lipoprotein and intermediatedensity lipoprotein, in addition to LDL-C particles, become trapped in blood vessel walls and have been demonstrated in human atherosclerotic plaques. ${ }^{11}$ Transient hypertriglyceridemia, induced by intravenous infusion of a triglyceride emulsion, was associated with decreased vascular reactivity in young healthy men who had no risk factors for coronary heart disease (CHD). ${ }^{12}$ Chronic hypertriglyceridemia was independently associated with endothelial dysfunction in an observational study of patients with normal LDL-C. ${ }^{13}$ Increased expression of adhesion cell molecules is considered to be a marker of endothelial cell dysfunction. ${ }^{14}$ An increase in cell adhesion molecules has been noted in patients with hypertriglyceridemia. ${ }^{14-15}$ Many prospective epidemiological studies have reported a positive relationship between serum triglyceride levels and incidence of CHD. ${ }^{16-18}$

\section{Materials and Methods}

This case control study was carried out in Department of Medicine, Dhaka Medical College Hospital from January 2013 to June 2013. A total of 100 Ischemic stroke patients who met the inclusion criteria were recruited as cases from the admitted patient of Medicine Department, DMCH. Age and sex matched apparently healthy persons were recruited as controls. Those who give informed written consent were finally enrolled in this study. All patients presenting with ischemic stroke, confirmed by CT scan of head/MRI of brain from 01 day to 6 months were included as cases. Patients of venous thrombosis, severely ill patients, those who were taking anti lipid drugs, history of Cardioembolic events -
AF, MI (within 6 weeks of acute stroke), prosthetic heart valve, endocarditis were excluded from this study.

Stroke was defined as a clinical syndrome characterized by rapidly developing clinical symptoms and/or signs of focal and at times global loss of brain function, with symptoms lasting $>24$ hours or leading to earliar death, and with no apparent cause other than that of vascular origin. Hypertriglyceridemia is defined as plasma levels of $\mathrm{TG} \geq 200$ $\mathrm{mg} / \mathrm{dL}^{12}$. (it corresponds to a high hypertriglyceridemia according to the ATP III).Serum total cholesterol, HDL cholesterol (HDL-C), LDL cholesterol (LDL-C) and triglycerides were measured by standard enzymatic procedures.

After collection of information, these data were checked, verified for consistency and edited for result. After editing and coding, the coded data were entered directly into the computer by using software. Data cleaning validation and analysis were performed using the SPSS $\backslash$ PC software and graph and chart by MS Excel. The result was presented in tables in mean, standard deviation (SD) and percentage. A "p" value $<0.5$ were considered as significant.

\section{Results:}

100 patients with ischemic stroke and 100 control subjects were included in the study. It was observed that male were predominant in both groups which was $80(80.0 \%)$ in case group and $84(84.0 \%)$ in control group. The difference was not statistically significant $(\mathrm{p}>0.05)$ between two groups.

Among the study patients according to past medical history $(n=200)$ it was observed that more than two third $(68.0 \%)$ in cases and one fourth $(25.0 \%)$ in controls patients had hypertension. Ten $(10.0 \%)$ patients had diabetes in cases and $4(4.0 \%)$ in controls. Twelve $(12.0 \%)$ in cases and 2 $(2.0 \%)$ in controls patients had heart disease. Hypertension and heart disease difference was statistically significant $(\mathrm{p}<0.05)$ between two groups. In this Normal triglycerides were found in $52(52.0 \%)$ cases and in $72(72.0 \%)$ of control. The mean TG was found to be $179.9 \pm 62.8 \mathrm{mg} / \mathrm{dl}$ in cases and $148.0 \pm 51.9 \mathrm{mg} / \mathrm{dl}$ in controls. Desirable cholesterol was found $16(16.0 \%)$ in cases and $25(25.0 \%)$ in controls. The mean cholesterol found was $238.0 \pm 4.0 \mathrm{mg} / \mathrm{dl}$ in cases and $213.0 \pm 42.0$ in controls. Optimal LDL was found $12(12.0 \%)$ and $18(18.0 \%)$ in case and control group respectively. Mean LDL was found to be $167.0 \pm 35.2 \mathrm{mg} / \mathrm{dl}$ in cases and $141.0 \pm 36.1 \mathrm{mg} / \mathrm{dl}$ in controls. Low HDL was found in 64 $(64.0 \%)$ cases and $26(26.0 \%)$ in controls. Mean HDL was found to be $41.2 \pm 10.6 \mathrm{mg} / \mathrm{dl}$ in case group and $49.0 \pm 8.6$ $\mathrm{mg} / \mathrm{dl}$ in control group. The difference was statistically significant $(\mathrm{p}<0.05)$ between two groups. 
Table-I

Distribution of the study patients according to age $(n=200)$

\begin{tabular}{|c|c|c|c|c|c|}
\hline \multirow[t]{2}{*}{ Age (years) } & \multicolumn{2}{|c|}{$\begin{array}{c}\text { Case } \\
(n=100)\end{array}$} & \multicolumn{2}{|c|}{$\begin{array}{l}\text { Control } \\
(n=100)\end{array}$} & \multirow[t]{2}{*}{$\begin{array}{c}\mathrm{P} \\
\text { value }\end{array}$} \\
\hline & $\mathrm{n}$ & $\%$ & $\mathrm{n}$ & $\%$ & \\
\hline $26-35$ & 4 & 4.0 & 3 & 3.0 & \\
\hline $36-45$ & 8 & 8.0 & 6 & 6.0 & \\
\hline $46-55$ & 24 & 24.0 & 25 & 25.0 & \\
\hline $56-65$ & 20 & 20.0 & 19 & 19.0 & \\
\hline $66-75$ & 28 & 28.0 & 33 & 33.0 & \\
\hline$>75$ & 16 & 16.0 & 14 & 14.0 & \\
\hline Mean \pm SD & \multicolumn{2}{|c|}{$61.0 \pm 8.3$} & \multicolumn{2}{|c|}{$60.5 \pm 8.1$} & $0.667^{\mathrm{ns}}$ \\
\hline Range (min,max) & \multicolumn{2}{|c|}{$(26-77)$} & \multicolumn{2}{|c|}{$(27-79)$} & \\
\hline
\end{tabular}

Table-II

Distribution of the study patients according to occupational status $(n=200)$

\begin{tabular}{lcccc}
\hline Occupational status & \multicolumn{2}{c}{$\begin{array}{c}\text { Case } \\
(\mathrm{n}=100)\end{array}$} & \multicolumn{2}{c}{ Control } \\
& $\mathrm{n}$ & $\mathrm{n}=100)$ & $\mathrm{n}$ & $\%$ \\
\hline House-wife & 20 & 20.0 & 19 & 19.0 \\
Day labour & 28 & 28.0 & 30 & 30.0 \\
Non govt. service & 16 & 16.0 & 15 & 15.0 \\
Govt. service & 8 & 8.0 & 7 & 7.0 \\
Business & 20 & 20.0 & 22 & 22.0 \\
Others-Farmer & 8 & 8.0 & 7 & 7.0 \\
\hline
\end{tabular}

Table-III

Distribution of the study patients according to complications $(n=200)$

\begin{tabular}{lccccc}
\hline Complications & \multicolumn{2}{c}{ Case } & \multicolumn{2}{c}{ Control } & P \\
& \multicolumn{2}{c}{$(\mathrm{n}=100)$} & \multicolumn{2}{c}{$(\mathrm{n}=100)$} & value \\
& $\mathrm{n}$ & $\%$ & $\mathrm{n}$ & $\%$ & \\
\hline $\begin{array}{l}\text { Weakness of the } \\
\text { body (Rt) }\end{array}$ & 64 & 64.0 & 0 & 0.0 & $0.001^{\mathrm{s}}$ \\
$\begin{array}{l}\text { Weakness of the } \\
\text { body (Lt) }\end{array}$ & 36 & 36.0 & 0 & 0.0 & $0.001^{\mathrm{s}}$ \\
$\begin{array}{l}\text { Aphasia } \\
\text { Unconsciousness }\end{array}$ & 40 & 40.0 & 0 & 0.0 & $0.001^{\mathrm{s}}$ \\
$\begin{array}{l}\text { Headache } \\
\text { Vomiting }\end{array}$ & 11 & 25.0 & 0 & 0.0 & $0.001^{\mathrm{s}}$ \\
Others & 16 & 16.0 & 8 & 8.0 & $0.469^{\mathrm{ns}}$ \\
\hline & 8 & 8.0 & 88 & 88.0 & $0.001^{\mathrm{s}}$ \\
\hline
\end{tabular}

Table-IV

Distribution of the study patients according to past medical history $(n=200)$

\begin{tabular}{lccccc}
\hline Past medical history & $\begin{array}{c}\text { Case } \\
(\mathrm{n}=100)\end{array}$ & \multicolumn{2}{c}{$\begin{array}{c}\text { Control } \\
(\mathrm{n}=100)\end{array}$} & $\begin{array}{c}\text { P } \\
\text { value }\end{array}$ \\
& $\mathrm{n}$ & $\%$ & $\mathrm{n}$ & $\%$ & \\
\hline $\begin{array}{l}\text { Hypertension } \\
\text { Yes }\end{array}$ & 68 & 68.0 & 25 & 25.0 & $0.001^{\mathrm{s}}$ \\
$\quad$ No & 32 & 32.0 & 75 & 75.0 & \\
$\begin{array}{l}\text { Diabetes } \\
\text { Yes }\end{array}$ & 10 & 10.0 & 4 & 4.0 & $0.096^{\mathrm{ns}}$ \\
$\quad$ No & 90 & 90.0 & 96 & 96.0 & \\
Heart Disease & & & & & \\
$\quad$ Yes & 12 & 12.0 & 2 & 2.0 & $0.005^{\mathrm{s}}$ \\
$\quad$ No & 88 & 88.0 & 98 & 98.0 & \\
\hline
\end{tabular}

Table-V

Distribution of the study patients according to fasting lipid profile $(n=200)$

\begin{tabular}{|c|c|c|c|c|c|c|}
\hline \multirow[t]{2}{*}{ Fasting lipid profile } & & \multicolumn{2}{|c|}{ Case $(n=100)$} & \multicolumn{2}{|c|}{ Control $(n=100)$} & \multirow[t]{2}{*}{ P value } \\
\hline & & $\mathrm{n}$ & $\%$ & $\mathrm{n}$ & $\%$ & \\
\hline \multirow[t]{6}{*}{ Triglycerides (TG) } & Normal $(<150 \mathrm{mg} / \mathrm{dl})$ & 52 & 52.0 & 72 & 72.0 & \\
\hline & Borderline high (150-199 mg/dl) & 32 & 32.0 & 22 & 22.0 & \\
\hline & High $(200-499 \mathrm{mg} / \mathrm{dl})$ & 14 & 14.0 & 6 & 6.0 & \\
\hline & Very high $(>500 \mathrm{mg} / \mathrm{dl})$ & 2 & 2.0 & 0 & 0.0 & \\
\hline & Mean \pm SD & \multirow{2}{*}{\multicolumn{2}{|c|}{$\begin{array}{r}179.9 \pm 62.8 \\
(110,520)\end{array}$}} & \multirow{2}{*}{\multicolumn{2}{|c|}{$\begin{array}{c}148.0 \pm 51.9 \\
(100,290)\end{array}$}} & $0.001^{\mathrm{s}}$ \\
\hline & Range (min,max) & & & & & \\
\hline \multirow[t]{4}{*}{ Total cholesterol } & Desirable $(<200 \mathrm{mg} / \mathrm{dl})$ & 16 & 16.0 & 25 & 25.0 & \\
\hline & Increased $(>200 \mathrm{mg} / \mathrm{dl})$ & 84 & 84.0 & 75 & 75.0 & \\
\hline & Mean \pm SD & \multirow{2}{*}{\multicolumn{2}{|c|}{$\begin{array}{c}238.0 \pm 43.0 \\
(150,280)\end{array}$}} & \multirow{2}{*}{\multicolumn{2}{|c|}{$\begin{array}{c}213.0 \pm 42.0 \\
(150,250)\end{array}$}} & $0.001^{\mathrm{s}}$ \\
\hline & Range (min, $\max )$ & & & & & \\
\hline \multirow[t]{4}{*}{ Low-density lipoprotein (LDL) } & Optimal $(<130 \mathrm{mg} / \mathrm{dl})$ & 12 & 12.0 & 18 & 18.0 & \\
\hline & Increased $(>130 \mathrm{mg} / \mathrm{dl})$ & 88 & 88.0 & 82 & 82.0 & \\
\hline & Mean \pm SD & \multirow{2}{*}{\multicolumn{2}{|c|}{$\begin{array}{r}167.0 \pm 35.2 \\
(120,189)\end{array}$}} & \multirow{2}{*}{\multicolumn{2}{|c|}{$\begin{array}{r}141.0 \pm 36.1 \\
(100,159)\end{array}$}} & $0.001^{\mathrm{s}}$ \\
\hline & Range (min,max) & & & & & \\
\hline \multirow[t]{4}{*}{ High-density lipoprotein (HDL) } & Low $(<40 \mathrm{mg} / \mathrm{dl})$ & 64 & 64.0 & 26 & 26.0 & \\
\hline & Increased $(>40 \mathrm{mg} / \mathrm{dl})$ & 36 & 36.0 & 74 & 74.0 & \\
\hline & Mean \pm SD & \multirow{2}{*}{\multicolumn{2}{|c|}{$\begin{array}{c}41.2 \pm 10.6 \\
(38,60)\end{array}$}} & \multirow{2}{*}{\multicolumn{2}{|c|}{$\begin{array}{l}49.0 \pm 8.6 \\
(39,66)\end{array}$}} & $0.001^{\mathrm{s}}$ \\
\hline & Range (min,max) & & & & & \\
\hline
\end{tabular}




\section{Discussion:}

This case control study was carried out with an aim to determine the level of triglyceride among ischemic stroke patients and to measure and compare the serum triglyceride level including comparing partial demographic variation between cases and controls.

In this present study it was observed that the age of $28.0 \%$ patients in case group and $33.0 \%$ in control group was within 66-75 years and the mean age was $61.0 \pm 8.3$ years varied from $26-77$ years in case group and $60.5 \pm 8.1$ years varied from $27-79$ years in control group, which was almost alike between two groups, no difference was found. Similarly, Tanne et al. ${ }^{11}$ showed the mean age was $61.8 \pm 6.5$ years Ischemic Stroke/TIA and 59.6 7.1 years in no CVD patients. Similarly, Bowman et al. ${ }^{18}$ showed the mean age was $61.5 \pm 7.2$ years and $59.9 \pm 8.7$ years in case and control respectively. On the other hand, Hsieh et al. ${ }^{19}$ has observed higher mean age in Ischemic Stroke Group and control group, which were $69 \pm 11$ years and $63 \pm 23$ years respectively. They have stated that the higher age range maybe due to increased life expectancy, geographical and racial influences may have significant impacts on Ischemic Stroke.

In this current study it was observed that male were predominant in both groups which was $80.0 \%$ in case group and $84.0 \%$ in control group and male to female ratio was almost 4:1 in both groups. The difference was not statistically significant $(p>0.05)$ between two groups. Similar observations regarding the sex incidence were also made by Tanne et al. ${ }^{11}$, Hsieh et al. ${ }^{19}$

Regarding the complications it was observed in this present study that weakness of the body (Rt) $(64.0 \%)$, weakness of the body (Lt) (36.0\%), aphasia (40.0\%) and unconsciousness $(25.0 \%)$ were more common in the case group whereas headache was present in $11.0 \%$ and vomiting $16.0 \%$ in this group. Islam ${ }^{20}$ showed that $50.0 \%$ of the Ischemic patients presented with left sided abnormality, $40.0 \%$ had right sided, $10.0 \%$ had both sided abnormality and $24.0 \%$ had vomiting. Report from Akbar and Mushtaq ${ }^{21}$ showed that the bilateral stroke was $15.5 \%$ in the 103 study patients.

Regarding the past medical history it was observed in this current study that more than two third of patients $(68.0 \%)$ in cases and one fourth $(25.0 \%)$ in controls had hypertension. Ten percent patients had diabetes in cases and $4.0 \%$ in controls. Twelve percent patients in cases and $2.0 \%$ in controls had heart disease. Hypertension and heart disease were significantly $(\mathrm{p}<0.05)$ higher in case groups. Tanne et al. ${ }^{11}$ showed hypertension, in $43.0 \%$ Ischemic Stroke/TIA group and $32.0 \%$ in NO CVD group. Diabetes mellitus found $34.0 \%$ and $20.0 \%$ in Ischemic Stroke/TIA and No CVD respectively.
Hypertension is the most important modifiable risk factor for both ischemic stroke and ICH. However, hypertension appears to be a stronger risk factor for ICH than for ischemic stroke reported by Qureshi et al. ${ }^{23}$, Lewington et al. ${ }^{24}$ The risk of stroke increases exponentially with increasing diastolic blood pressure (DBP) mentioned by MacMahon et al. ${ }^{25}$ However, hypertension is a highly preventable risk factor; a systematic review of 17 randomized clinical trials showed that lowering DBP by $5-6 \mathrm{mmHg}$ and systolic blood pressure (SBP) by $10-12 \mathrm{mmHg}$ resulted in a $38 \%$ reduction in strokes. ${ }^{23-25}$ Hypertension alone may also increase the risk of rupture related to degenerative changes of small arterioles documented by Qureshi et al. ${ }^{23}$ In this present study it was observed that $28.0 \%$ patients had diabetes mellitus in case group and $7.0 \%$ in control groups. $\mathrm{Al}$ most one third (32.0\%) patients had hypertension in case group and 19.0\% in control group. Alost one fourth (24.0\%) patients had stroke in case group and $9.0 \%$ in control group. Only $4.0 \%$ and $19.0 \%$ had obesity in cases and controls respectively. Eight (8.0\%) patients had dyslipidemia in cases and $18.0 \%$ in controls. diabetes mellitus, hypertension and stroke were significantly $(\mathrm{p}<0.05)$ higher in case group, however obesity and dyslipidemia were significantly $(p<0.05)$ higher in control group. Bowman et al. ${ }^{18}$ found diabetes $12.8 \%$ and $3.4 \%$ in case and control respectively.

In only some a severe hypercholesterolemia (total-C levels $>8 \mathrm{mmol} / \mathrm{L}$ ) was associated with ischemic stroke obtained by Lindenstrom et al. ${ }^{26}$ or non fatal stroke in men reported by Wannamethee et al. ${ }^{27}$. It was observed in this current study that normal triglyceride was found $52.0 \%$ in cases and $72.0 \%$ in control. The mean TG was found $179.9 \pm 62.8 \mathrm{mg} /$ $\mathrm{dl}$ in cases and $148.0 \pm 51.9 \mathrm{mg} / \mathrm{dl}$ in controls, which was significantly $(\mathrm{p}<0.05)$ higher in case group. Austin MA et al. ${ }^{13}$ found that the mean average of TG was $169.71 \mathrm{mg} / \mathrm{dl}$ in patients and $148.68 \mathrm{mg} / \mathrm{dl}$ in controls. Tanne et al. ${ }^{11}$ showed the mean TG $178 \pm 108 \mathrm{mg} / \mathrm{dL}$ in Ischemic Stroke/ TIA and $164 \pm 102 \mathrm{mg} / \mathrm{dL}$ in No CVD. Bowman et al. ${ }^{18}$ (2003) obtained that the mean average of TG was $192.3 \pm 155.9 \mathrm{mg} / \mathrm{dl}$ in patients and $157.0 \pm 93.0 \mathrm{mg} / \mathrm{dl}$ in controls.

In this series it was observed that desirable cholesterol was found $16.0 \%$ and $25.0 \%$ in case and controls respectively. The mean cholesterol was found $238.0 \pm 4.0 \mathrm{mg} / \mathrm{dl}$ in cases and $213.0 \pm 42.0$ in controls. That was significantly $(p<0.05)$ higher in case group. Tanne et al. ${ }^{15}$ found the mean total cholesterol $228 \pm 43 \mathrm{mg} / \mathrm{dL}$ and $225 \pm 43 \mathrm{mg} / \mathrm{dL}$ in Ischemic Stroke/TIA and No CVD respectively. Similarly, Bowman et al. ${ }^{18}$ obtained that the mean TC level was $231.7 \pm 51.1$ $\mathrm{mg} / \mathrm{dL}$ in case group and $228.6 \pm 46.5 \mathrm{mg} / \mathrm{dL}$ in control group. Similar identical findings also found by Hsieh et al. ${ }^{19}$. 
In this study it was observed that optimal LDL was found $12.0 \%$ in case and $18.0 \%$ in control group. Mean LDL was found $167.0 \pm 35.2 \mathrm{mg} / \mathrm{dl}$ in cases and $141.0 \pm 36.1 \mathrm{mg} / \mathrm{dl}$ in controls, which was significantly $(\mathrm{p}<0.05)$ higher in case group. Tanne et al. ${ }^{11}$ found the mean LDL-C level was $157 \pm 38 \mathrm{mg} / \mathrm{dL}$ in Ischemic Stroke/TIA and $54 \pm 37 \mathrm{mg} / \mathrm{dL}$ in No CVD. Similar findings also obtained by Hsieh et al. ${ }^{19}$. The above findings are consistent with the current study.

A low HDL-C level has been reported by Bowman et al. ${ }^{18}$ to be associated with ischemic stroke in many studies. In another, hypertriglyceridemia was weakly associated with ischemic stroke in women but not in men obtained by Abbott RD et al. ${ }^{22}$. In this present series it was observed that low HDL was found $64.0 \%$ and $26.0 \%$ in case and controls groups respectively. Mean HDL was found $41.2 \pm 10.6 \mathrm{mg} /$ $\mathrm{dl}$ in case group and $49.0 \pm 8.6 \mathrm{mg} / \mathrm{dl}$ in control group, which was significantly $(\mathrm{p}<0.05)$ lower in case group. Bowman et al. ${ }^{18}$ showed the mean HDL-C to be $49.0 \pm 15.9 \mathrm{mg} / \mathrm{dL}$ and $52.4 \pm 16.0$ in cases and control respectively. Similarly, Tanne et al. ${ }^{11}$ and Hsieh et al. ${ }^{19}$ had observed identical HDL level of the patients and thus, support the present study.

Laloux et al. ${ }^{17}$ showed in controlled study that ischemic stroke/TIA is associated significantly with a higher level of total-C, LDL-C, HDL-C (inversely) and TG. Therefore, their results confirm that hypercholesterolemia and hypertriglyceridemia may be a risk factor for ischemic cerebrovascular disease. However, the issue of whether hyperlipidemia is related more to any particular stroke subtype remains unsettled. Although two studies have shown that a high level of total-C and TG was significantly associated with atherothrombotic stroke as compared to control. The above findings closely resemble the findings of the current study.

\section{Conclusion}

This study was undertaken to evaluate the association of hyper-triglyceridemia with ischemic stroke. Ischemic Stroke was more common in $6^{\text {th }}$ and $7^{\text {th }}$ decade and male predominant. Weakness of the body (Rt), weakness of the body (Lt), aphasia and unconsciousness were the more common complications of ischemic stroke patients. Hypertension, heart disease, smoking, diabetes mellitus were significantly $(\mathrm{p}<0.05)$ associated with ischemic stroke. On the other hand ischemic stroke is associated significantly with a higher level of total-C, LDL-C, HDL-C (inversely), and TG. Therefore, this current study result confirms that hypercholesterolemia and hypertriglyceridemia may be a risk factor for ischemic stroke.

\section{Limitations of the study}

1. The study population was selected from one selected hospital in Dhaka city, so that the results of the study may not be reflect the exact picture of the country.

2. The present study was conducted within a very short period of time.

3. Small sample size was also a limitation of the present study. Therefore, in future further study may be under taken with large sample size.

\section{Conflict of Interest : None}

\section{References:}

1. Shi F, Hart RG, Sherman DG, Tegeler CH. Stroke in the People's Republic of China. Stroke. 1989;20:1581-1585.

2. Murray CJL, Lopez AD, eds. The Global Burden of Disease. Boston, Mass: Harvard University Press. 1996;1:221-228.

3. Feigin VL. Stroke in developing countries: can the epidemic be stopped and outcomes improved? Lancet Neurol. 2007;6:94-97.

4. Strong K, Mathers C, Bonita R. Preventing stroke: saving lives around the world. Lancet Neurol. 2007;6:182-187.

5. O'Donnell M, Yusuf S. Tackling the global burden of stroke: the need for large-scale international studies. Lancet Neurol. 2009;8:306-307.

6. Ariesen MJ, Claus SP, Rinkel GJ, Algra A. Risk factors for intracerebral hemorrhage in the general population: a systematic review. Stroke. 2003;34:2060-2065.

7. Donnan GA, Hankey GJ, Davis SM. Intracerebral haemorrhage: a need for more data and new research directions. Lancet Neurol. 2010;9:133-134.

8. Wittrup HH, Tybjaerg-Hansen A, Jensen GB, Nordestgaard BG. Lipoprotein lipase mutations, plasma lipids and lipoproteins, and risk of ischemic heart disease. Circulation. 1999;99:2901-2907.

9. Third Report of the National Cholesterol Education Program (NCEP) Expert Panel on Detection, Evaluation, and Treatment of High Blood Cholesterol in Adults (Adult Treatment Panel III) final report. Circulation. 2002; 106:3143.

10. Austin MA, Hokanson JE, Edwards KL: Hypertriglyceridemia as a cardiovascular risk factor. Am J Cardiol. 1998;81:7B-12B.

11. Tanne D, Koren-Morag N, Graff E, Goldbourt U, the BIP Study Group: Blood lipids and first-ever ischemic stroke/ transient ischemic attack in the Bezafibrate Infarction Prevention (BIP) Registry: high triglycerides constitute an independent risk factor. Circulation. 2001;104:2892-2897. 
12. Patel A, Barzi F, Jamrozik K, Lam TH, Ueshima H, Whitlock G, et al. Asia Pacific Cohort Studies Collaboration: Serum triglycerides as a risk factor for cardiovascular diseases in the Asia-Pacific region. Circulation. 2004;110:2678-2686..

13. Austin MA, Hokanson JE, Edwards KL. Hypertriglyceridemia as a cardiovascular risk factor. Am J Cardiol. 1998;81:7B-12B.

14. Hulley SB, Rosenman RH, Bawol RD, Brand RJ. Epidemiology as a guide to clinical decisions: the association between triglyceride and coronary heart disease. N Engl J Med. 1980;302:1383-1389.

15. Leonards C, Ebinger M, Batluk J, Malzahn U, Heuschmann $\mathrm{P}$, Endres $\mathrm{M}$ et al. The role of fasting versus non-fasting triglycerides in ischemic stroke: a systematic review. 2010:133 -42.

16. Antonios N, Angiolillo DJ, Silliman S. Hypertriglyceridemia and Ischemic Stroke. Eur Neurol. 2008;(60):269-278.

17. Laloux P, Galanti L, Jamart J. Lipids in ischemic stroke subtypes Acta neurol Belg. 2004;(104):13-19.

18. Bowman TS, Sesso HD, Ma J, Kurth T, Kase CS, Stampfer $\mathrm{MJ}$ et al. Cholesterol and the Risk of Ischemic Stroke. Stroke. 2003;34:2930-2934.

19. Hsieh MS, Yu SC, Hsueh YM, Chiu WT, Lee HM. Gene Variants of Arachidonate 5-Lipoxygenase-Activating Protein $(A L O X 5 A P)$ and Risks of Ischemic Stroke in the Taiwanese Population. Clinical Molecular Medicine. 2008;1(1):1-5.
20. Islam A. Ischemic stroke and its relation with Hypertension. Holy Family R.C.M.C Hospital, Dhaka. BCPS (Dissertation). 2010:38-74.

21. Akbar DH and Mushtaq M. Clinical profile of stroke: The experience at King Abdulaziz University. SQU Journal for scientific research. 2001;1: 35-38.

22. Abbott RD, Yin Y, Reed DM, Yano K. Risk of stroke in male cigarette smokers. N Engl J Med. 1986;315(12): 717-20.

23. Qureshi AI, Tuhrim S, Broderick JP, Batjer HH, Hondo H, Hanley DF. Spontaneous intracerebral hemorrhage. N Engl J Med. 2001;344(19):1450-60.

24. Lewington S, Clarke R, Qizilbash N, Peto R, Collins R. Age-specific relevance of usual blood pressure to vascular mortality: a meta-analysis of individual data for one million adults in 61 prospective studies. Lancet. 2002; 360(9349): 1903-13.

25. MacMahon S, Rodgers A. Blood pressure, antihypertensive treatment and stroke risk. J Hypertens Suppl. 1994;(10): S5-14.

26. Lindenstrom E, Boysen G, Nyboe J. Influence of total cholesterol, high density lipoprotein cholesterol, and triglycerides on risk of cerebrovascular disease : the Copenhagen City Heart Study. BMJ. 1994;309:11-15.

27. Wannamethee SG, Shaper AG, Ebrahim S. HDLCholesterol, total cholesterol, and the risk of stroke in middle-aged British men. Stroke. 2000;31:1882-1888. 